\title{
Investigating Ataxia in Childhood
}

Emily Petley ${ }^{1}$, Manish Prasad ${ }^{2}$, Shalini Ojha ${ }^{1,3}$, William P Whitehouse ${ }^{1,2}$

1. Academic Division of Child Health, School of Medicine, University of Nottingham, Nottingham, UK

2. Nottingham Children's Hospital, Nottingham University Hospitals NHS Trust, Nottingham, UK

3. Derbyshire Children's Hospital, Derby Teaching Hospitals NHS Foundation Trust, Derby, UK

\section{Correspondence to:}

Dr William P Whitehouse, Academic Division of Child Health, E Floor East Block, Queen's Medical Centre, Nottingham, NG9 2UH

william.whitehouse@nottingham.ac.uk

\section{Keywords:}

Neurology, General Paediatrics, Accident and Emergency

\section{Abstract}

Ataxia is a common presentation to an acute paediatric unit and it can often be difficult to determine the cause. It is important to distinguish between serious causes, for example brain tumours and encephalitis, and more benign causes in order to guide investigations and treatment.

In this review we describe the different types of ataxia, the causes associated with them, the examination findings and what investigations to perform in order to make a diagnosis. 


\section{INTRODUCTION}

Ataxia is a concerning symptom and sign for both the parents and the clinician, so children generally present within a few days of onset. However, it can also present insidiously, and may be ignored by health professionals initially, until it becomes more obvious. Clinical assessment will aim to determine the type of ataxia, and any associated symptoms and signs. As always a careful history and clinical assessment will inform investigation and management.

The most common causes of ataxia in children referred to a tertiary paediatric neurology service for acute ataxia were post-infectious cerebellar ataxia ( $59 \%$ of cases), drug intoxication ( $8 \%$ of cases) and opsoclonus myoclonus ataxia (8\% of cases). ${ }^{(1)}$ However, in general practice, hospital or community paediatric settings, or in a children's Emergency Department drug intoxication will account for a much higher proportion, and opsoclonus myoclonus ataxia will be extremely rare. ${ }^{(2)}$

\section{WHAT EXACTLY IS ATAXIA?}

Ataxia is an abnormality of movement characterised by impairments in coordination, typically with jerky or wobbly or unsteady movements, associated with compensatory movements and postures. It can be seen sometimes in combination with other abnormal movements and postures. These can help establish the differential diagnosis.

The term is derived from the Greek $\alpha-\tau \dot{\alpha} \xi \iota \varsigma$ meaning [lack of] + [order], i.e. un(co)ordinated. It is useful to realise that not all ataxia is cerebellar ataxia and it is important to distinguish between the types (table 1). Furthermore, the presentation and evolution of ataxia can be acute, over hours or a few days, episodic relapsing and remitting, chronic non-progressive, or chronic progressive over weeks, months or years. 
Table 1: Neurological types of Ataxia

\begin{tabular}{|c|c|c|}
\hline $\begin{array}{l}\text { Type of } \\
\text { Ataxia }\end{array}$ & Symptoms and signs & Aetiology \\
\hline $\begin{array}{l}\text { Cerebellar } \\
\text { Ataxia }\end{array}$ & $\begin{array}{l}\text { - Intention tremor with dysmetria, } \\
\text { - } \quad \text { Dys, past pointing } \\
\text { - Nystagmus - think: ataxia of } \\
\text { - } \quad \text { Slurred and/ornal ocular movements } \\
\text { think: ataxia of speech } \\
\text { - Wide-based jerky and unsteady } \\
\text { - gait, an ataxic gait } \\
\text { Titubation - head nods are ataxia } \\
\text { of axial posture } \\
\text { Hypotonia } \\
\text { See Box } 3\end{array}$ & $\begin{array}{l}\text { Damage to or disorders of the cerebellum, } \\
\text { or its connections, e.g. alcohol (ethanol) } \\
\text { intoxication, acute cerebellitis, ADEM, } \\
\text { posterior fossa tumours, spinocerebellar } \\
\text { ataxias. }\end{array}$ \\
\hline $\begin{array}{l}\text { Vestibular } \\
\text { Ataxia }\end{array}$ & 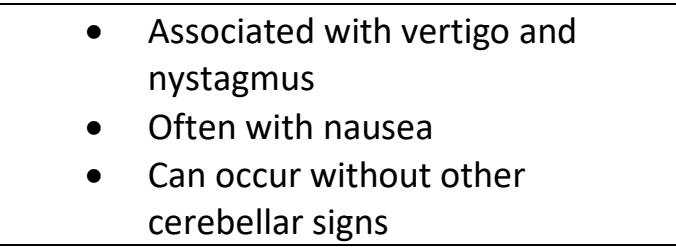 & Labyrinthitis and middle ear disease. \\
\hline $\begin{array}{l}\text { Sensory } \\
\text { Ataxia }\end{array}$ & $\begin{array}{l}\text { - Loss of joint position sense } \\
\text { - Positive or abnormal Romberg's } \\
\text { test: after standing relatively } \\
\text { stably with eyes open, the child } \\
\text { becomes much more ataxic or } \\
\text { falls over when they close their } \\
\text { eyes }\end{array}$ & $\begin{array}{l}\text { Caused by the loss of sense of position of } \\
\text { body parts in the environment. } \\
\text { Seen in children with sensory neuropathies } \\
\text { and or spinal cord dorsal column } \\
\text { pathology, e.g. in Friedreich's Ataxia, } \\
\text { Subacute Combined Degeneration of the } \\
\text { Cord. }\end{array}$ \\
\hline $\begin{array}{l}\text { Ataxia due to } \\
\text { muscle } \\
\text { weakness }\end{array}$ & $\begin{array}{l}\text { Usually clinically obvious, with significant } \\
\text { weakness in muscles of the ataxic limbs. }\end{array}$ & $\begin{array}{l}\text { Typically seen in patients with GBS, milder } \\
\text { versions of Spinal Muscle Atrophy (SMA) } 2 \\
\text { or SMA 3, due to motor neurone loss with } \\
\text { the remaining neurones each innervating } \\
\text { many more fibres than usual. This causes } \\
\text { jerky movements. }\end{array}$ \\
\hline $\begin{array}{l}\text { Functional or } \\
\text { Medically } \\
\text { Unexplained } \\
\text { Ataxia }\end{array}$ & $\begin{array}{l}\text { Present with inconsistent clinical findings, } \\
\text { for example a narrow stance and } \\
\text { unsteady gait. } \\
\text { They may have ataxia and additional } \\
\text { functional neurological symptoms and } \\
\text { signs. }\end{array}$ & $\begin{array}{l}\text { Often no underlying cause can be found, } \\
\text { although functional symptoms and signs } \\
\text { can be seen in Post-Traumatic Stress } \\
\text { Disorder, even when the patient denies } \\
\text { feeling anxious or stressed. } \\
\text { A comprehensive review is beyond the } \\
\text { scope of this article. }\end{array}$ \\
\hline
\end{tabular}


ADEM: Acute Disseminated EncephaloMyelitis, GBS: Guillain-Barre syndrome, SMA: Spinal Muscular. Atrophy.

The most common causes of ataxia are discussed below. They are grouped and discussed according to the timing of the presentation of the ataxia, rather than the type of ataxia.

\section{ACUTE ATAXIA}

The relative risk of different diagnoses depends on the clinical context. This was reviewed a few years ago..$^{(3,4)}$

We describe the common causes of acute ataxia below including the presenting symptoms, causative organisms and possible treatment options.

\section{Intoxication or Metabolic}

Intoxication causes many cases of acute ataxia, typically a cerebellar ataxia (table 1), but is underrepresented in case series based on hospitalisations. It accounts for as many as $30 \%$ of cases of acute ataxia in published series, and there may be no history of ingestion. The most common substances to cause intoxication with acute ataxia are alcohol (ethanol), benzodiazepines, phenytoin, and carbamazepine. ${ }^{(5,6)}$ Generally once the substance has been cleared by the body, the ataxia will resolve. In these situations, advice should always be sought from the local specialist poisons and toxins centre.

Ataxia will also commonly accompany confusion and stupor from hypoglycaemia, and any number of metabolic derangements before the advent of coma. 


\section{Cerebellitis / encephalitis and post-infectious cerebellar ataxia}

The most common causes of Acute Cerebellar Ataxia in tertiary paediatric neurology settings is cerebellitis and post-infectious cerebellar ataxia. It accounts for over $50 \%$ of cases. These children all have a recent history of infection and most are aged 1-6 years. ${ }^{(1)}$ It presents as a sudden onset ataxia over a maximum of 72 hours with other cerebellar signs (table 1), vomiting and irritability. In postinfectious cerebellar ataxia there is no fever, no signs of meningism, and the symptoms and signs are symmetrical. The most common infections to cause an acute post-infectious cerebellar ataxia are varicella zoster virus, coxsackie virus, Epstein-Barr virus (EBV), echovirus, enterovirus, parvovirus, measles, and mumps. ${ }^{(6,7)}$

Children with encephalitis usually present with fever, a decreased conscious level, focal neurological signs, and sometimes epileptic seizures: an acute encephalopathy. They may also have a cerebellar ataxia. Patients presenting with these symptoms need to be promptly started on empirical antibiotics and antivirals. Often the precise aetiology is not determined, but the patient improves with empirical treatment (review the decreased conscious level in children and young people guideline $^{(8)}$ and the encephalitis guideline. ${ }^{(9)}$

\section{Acute disseminated encephalomyelitis (ADEM)}

Acute disseminated encephalomyelitis (ADEM) is a rare inflammatory, demyelinating autoimmune disease that generally occurs within 2 weeks of an unremarkable viral infection, often of the upper respiratory tract (72\%). There are also a few reports of ADEM associated with vaccination. ${ }^{(10)}$

Children present with a cerebellar ataxia, fever, headache, vomiting, decreased conscious level, and sometimes seizures. The symptoms progress over 4 to 5 days and can include hemiparesis, optic neuritis, and a transverse myelitis. Most patients have improvement of their clinical symptoms 
within 3-6 months of the onset of disease. Treatment options include IV steroids, and patients require specialist tertiary paediatric neurology assessment. ${ }^{(11,12)}$

\section{Cerebellar abscess}

Cerebellar abscesses often present with cerebellar ataxia, fever and headache, but with no signs of meningism initially. They are generally caused by the extension of an infection, for example otitis media or mastoiditis. Generally, they present over a few days or weeks, but rupture of the abscess can result in a sudden onset, or worsening, of the ataxia.

\section{Posterior Circulation Cerebrovascular Event (Stroke)}

A posterior circulation stroke will present with sudden cerebellar ataxia. Other signs and symptoms include headache, focal weakness, numbness, vomiting, visual disturbances and difficulty with speech. $^{(5)}$

\section{Intracranial haemorrhage}

Intracranial haemorrhage into the posterior fossa or cerebellum, in the most severe case, will also present with a sudden-onset ataxia with visual disturbance and severe sudden-onset headache. It can be caused by a traumatic head injury and or rupture of an arteriovenous or other vascular malformation. These patients need urgent imaging and neurosurgical review.

\section{Labyrinthitis and Benign Paroxysmal Vertigo}

Labyrinthitis does not cause cerebellar ataxia, however in younger children it can be difficult to distinguish between a cerebellar ataxia and the effects of vertigo. Hearing loss and vomiting typically occur. 
BPV is considered a migraine variant in pre-school children, generally aged 2 to 6 years. They experience a severe and sudden onset of vertigo and ataxia. This can last several minutes to several hours and the child will have a normal clinical examination between attacks. They normally have associated nystagmus during the attack, but this can be difficult to elicit due to their fear related to the episode. ${ }^{(13)}$

These are both self-limiting conditions but may take many weeks to resolve.

\section{Opsoclonus myoclonus syndrome}

This is a syndrome characterised by opsoclonus, myoclonus and cerebellar ataxia. Opsoclonus is characteristic: comprising sudden short bursts of chaotic eye judders, lasting a second or two. Opsoclonus myoclonus syndrome generally has a sudden onset and can become a chronic disease. It is generally considered a paraneoplastic syndrome. Children who present with opsoclonus need extensive investigation, as $41-43 \%$ of children with Opsoclonus myoclonus syndrome have a malignancy, most frequently neuroblastoma. ${ }^{(14)}$ Early recognition of the characteristic opsoclonus should help early referral to paediatric neurology or paediatric oncology teams.

\section{Guillain-Barré Syndrome}

Guillain-Barre syndrome is a rapidly progressive autoimmune condition following an apparently benign infection such as an upper respiratory tract infection or gastroenteritis in the preceding six weeks. It typically presents with an ascending paralysis, from the distal lower limbs. The most common causative agents of GBS are are EBV, Campylobacter jejuni, haemophilus influenza, and cytomegalovirus.

Children present with ataxia or weakness or irritability and pain, and signs consistent with a lower motor neurone impairment, particularly depressed or more often absent deep tendon reflexes. The 
most common symptoms in a prospective study were ataxia (45\%), neuropathic pain (34\%) and inability to walk (24\%). These symptoms all progress to maximum severity by two to four weeks and it can take weeks to months for function to recover. ${ }^{(15)}$

Miller-Fisher Syndrome is a variant of GBS and consists of ataxia, opthalmoplegia, hypotonia and areflexia. ${ }^{(15)}$ Management involves early diagnosis, spine MRI, Nerve Conduction studies and sometimes CSF examination. Intravenous immunoglobulin or plasma exchange can speed-up recovery.

Other complications of GBS are respiratory failure, unsafe swallow, pain, and dysautonomia causing hypertension and arrhythmias. ${ }^{(16)}$

\section{Functional or Medically Unexplained Ataxia}

In children and young people with functional neurological symptoms and signs there are often characteristic but inconsistent clinical findings on examination. Video recordings are very helpful in reaching a diagnosis, together with a detailed history and careful neurological examination. An explanation of functional illness helps, explaining that dangerous or damaging conditions have been ruled out by history, examination and investigation. Multidisciplinary rehabilitation from professionals experienced in functional illness is often needed to help the child back to normal function.

\section{EPISODIC ATAXIA}

It is important to know about the conditions related to episodic ataxia as patients suffering from the disorder can repeatedly present to the emergency department and/or paediatric assessment unit. A brief description of common causes of episodic ataxia is mentioned in table 2 . 
Table 2: Causes of Episodic Ataxia

\begin{tabular}{|c|c|}
\hline Aetiology & Characteristic features \\
\hline $\begin{array}{l}\text { Glucose transporter } \\
\text { Type } 1 \text { deficiency }\end{array}$ & $\begin{array}{l}\text { - Impaired glucose transport to the brain secondary to a } \\
\text { transporter deficiency resulting in: } \\
\circ \text { Seizures with abnormal eye movements } \\
\circ \text { Cerebellar ataxia } \\
\circ \text { Spasticity and dystonia } \\
\circ \text { Cognitive impairment } \\
\text { - Symptoms that often present in infancy. } \\
\text { - Ketogenic diet is the treatment of choice. }{ }^{(17)}\end{array}$ \\
\hline $\begin{array}{l}\text { Urea cycle enzyme } \\
\text { disorders }\end{array}$ & $\begin{array}{l}\text { - Ornithine Transcarbamilase and other causes of } \\
\text { hyperammonaemia can cause cerebral damage. }{ }^{(18)} \\
\text { - It is important to measure an ammonia level in a child with } \\
\text { acute or episodic cerebellar ataxia, especially with any } \\
\text { impairment in conscious level. } \\
\text { - Other acute symptoms include: } \\
\text { ○ Impaired conscious level; } \\
\circ \quad \text { Seizures; } \\
\circ \quad \text { Visual loss; } \\
\circ \text { Vomiting. }\end{array}$ \\
\hline Aminoacidurias & $\begin{array}{l}\text { - Isovaleric academia is the most common of the } \\
\text { aminoacidurias. } \\
\text { - Children present with a severe acidaemia resulting in: } \\
\circ \text { Lethargy; } \\
\circ \text { Cerebellar ataxia; } \\
\circ \text { Vomiting; } \\
\circ \quad \text { Characteristic odour. }{ }^{(19)}\end{array}$ \\
\hline $\begin{array}{l}\text { Genetic Episodic } \\
\text { Ataxias (Types } 1 \text { to } 7 \text { ) }\end{array}$ & $\begin{array}{l}\text { - Episodic ataxia (EA)1 and EA2 account for most cases. } \\
\text { - Episodic ataxia type 1: } \\
\circ \quad \text { Brief episodes of gait and limb ataxia, lasting 1-2 } \\
\text { minutes } \\
\circ \quad \text { Start in childhood or adolescence. }{ }^{(20)} \\
\circ \quad \text { Children often have a normal examination between } \\
\text { attacks. } \\
\text { - Episodic ataxia type 2: } \\
\circ \quad \text { Triggered by emotional stress and exercise, } \\
\text { phenytoin, and caffeine. } \\
\circ \quad \text { Episodes can last a few hours to a few days. } \\
\circ \quad \text { Children with EA2 often have nystagmus either } \\
\text { during or between attacks. }{ }^{(20)}\end{array}$ \\
\hline $\begin{array}{l}\text { Spinocerebellar } \\
\text { Ataxias }\end{array}$ & $\begin{array}{l}\text { - Increasing number of genes have been identified. } \\
\text { - Present almost always in adults, but can present in } \\
\text { childhood. }\end{array}$ \\
\hline Basilar Migraine & $\begin{array}{l}\text { - Migraine with brainstem signs and symptoms including } \\
\text { diplopia, vertigo, and cerebellar ataxia. }\end{array}$ \\
\hline
\end{tabular}


- No associated limb weakness, but patients do complain of a headache.

- The patient is asymptomatic between episodes. ${ }^{(21)}$

\section{NON-PROGRESSIVE CHRONIC ATAXIA}

Some children will develop ataxia slowly, or it may emerge together with or after other signs (table

3).

Table 3: Non-Progressive Ataxia

\begin{tabular}{|c|c|}
\hline Aetiology & Characteristic features \\
\hline Ataxic Cerebral Palsy & $\begin{array}{l}\text { - A diagnosis of exclusion. } \\
\text { - Children present with: } \\
\quad \text { o Cerebellar ataxia } \\
\circ \text { Clear cerebellar injury on brain imaging } \\
\circ \quad \text { Low tone } \\
\quad \text { Impaired motor development. } \\
\text { - Every child diagnosed with ataxic cerebral palsy should be } \\
\text { re-assessed carefully with a view to making a more precise } \\
\text { diagnosis. }\end{array}$ \\
\hline $\begin{array}{l}\text { Structural } \\
\text { Malformations } \\
\text { including Cerebellar } \\
\text { Hypoplasia }\end{array}$ & $\begin{array}{l}\text { - } \text { Cerebellar ataxia } \\
\text { - Hypotonia } \\
\text { - } \text { Developmental delay including language } \\
\text { - Nystagmus } \\
\text { - Seizures }\end{array}$ \\
\hline
\end{tabular}

\section{PROGRESSIVE CHRONIC ATAXIAS}

An exhaustive list of progressive ataxias is beyond the scope of this article, but you should be aware of the more common diagnoses, listed below in table 4, and we would recommend early advice from your paediatric neurology, paediatric oncology, or paediatric neurosurgery team as indicated. Other rare genetic causes include the spinocerebellar ataxias more commonly seen in adults, and the pontocerebellar hypoplasias, usually picked up on MRI.

Table 4: Progressive Ataxias:

\begin{tabular}{|l|r|}
\hline Aetiology & Characteristic features \\
\hline $\begin{array}{l}\text { Posterior fossa space } \\
\text { occupying lesions } \\
\begin{array}{l}\text { (including cerebellar } \\
\text { tumour) }\end{array}\end{array}$ & $\begin{array}{l}40-50 \% \text { of brain tumours in children are located in the } \\
\text { posterior fossa. }\end{array}$ \\
\hline
\end{tabular}




\begin{tabular}{|c|c|}
\hline & $\begin{array}{l}\text { - Associated signs and symptoms of raised intracranial } \\
\text { pressure: } \\
\circ \quad \text { Papilloedema; } \\
\circ \quad \text { Cranial nerve palsies; } \\
\circ \text { Headaches. }\end{array}$ \\
\hline $\begin{array}{l}\text { Ataxia-Telangiectasia } \\
(A-T)\end{array}$ & $\begin{array}{l}\text { - Characterised by: } \\
\circ \text { Progressive cerebellar ataxia in pre-school years; } \\
\circ \text { Progressive neurodegeneration; } \\
\circ \text { Immunosuppression; } \\
\circ \text { Respiratory deterioration; } \\
\circ \text { Malignancy. } \\
\text { - Followed by: } \\
\circ \quad \text { Emergence of complex movement disorder; } \\
\circ \text { Oculomotor apraxia; } \\
\circ \text { Ocular telangiectasia. } \\
\text { - Children with classical A-T are generally wheelchair-bound } \\
\text { by the age of } 12 \text { years. } \\
\text { There is no proven treatment to cure or prevent } \\
\text { progression of the disease. }\end{array}$ \\
\hline Friedreich Ataxia & $\begin{array}{l}\text { - Most commonly presents in the adolescent years with signs } \\
\text { of a sensory ataxia. } \\
\text { Other symptoms include: } \\
\text { - Slowly progressive sensory gait ataxia; } \\
\circ \text { Progressive trunk and limb cerebellar ataxia; } \\
\circ \text { Muscle weakness; } \\
\circ \text { Scoliosis; } \\
\circ \text { Pes cavus. } \\
\text { - There is no effective treatment to stop the progression of } \\
\text { the disease. }\end{array}$ \\
\hline Multiple Sclerosis & $\begin{array}{l}\text { - Usually relapsing and remitting. } \\
\text { - } 5 \% \text { of the population with multiple sclerosis have their first } \\
\text { episode in childhood. }{ }^{(24)} \\
\text { - Present with a cerebellar ataxia with associated pyramidal } \\
\text { or corticospinal tract signs. }\end{array}$ \\
\hline Vitamin Deficiencies & $\begin{array}{l}\text { Subacute combined degeneration of the cord } \\
\qquad \quad \text { Early diagnosis and treatment with vitamin B12 can } \\
\text { lead to full recovery. }{ }^{(25)} \\
\text { Ataxia with Vitamin E deficiency } \\
\text { - Generally presents before the age of } 20 \text { years with } \\
\text { a gait disturbance and progressive cerebellar } \\
\text { ataxia. } \\
\text { - Also giving high dose vitamin E can prevent the } \\
\text { progression of the disease if the child is already } \\
\text { symptomatic. }{ }^{(26)}\end{array}$ \\
\hline
\end{tabular}




\begin{tabular}{|l|l|}
\hline Mitochondrial disease & $\begin{array}{l}\text { Cerebellar ataxia often seen, and sometime sensory ataxia } \\
\text { or ataxia associated with weakness with a neuropathy or } \\
\text { myopathy. }\end{array}$ \\
\hline $\begin{array}{l}\text { Neurological coeliac } \\
\text { disease }\end{array}$ & $\begin{array}{l}\text { Patients with coeliac disease can have a range of } \\
\text { neurological symptoms, including ataxia, whether or not } \\
\text { they have the gastrointestinal symptoms. }\end{array}$ \\
- It generally responds well to a gluten free diet and \\
symptoms can resolve fully.
\end{tabular}

\begin{tabular}{|c|c|}
\hline $\begin{array}{l}\text { Ataxia with } \\
\text { Oculomotor Apraxia } \\
\text { (AOA) - } \\
\text { Type } 1 \text { and Type } 2\end{array}$ & $\begin{array}{l}\text { - AOA Type } 1 \\
\text { ○ Presents in early childhood; } \\
\circ \text { Cerebellar ataxia; } \\
\circ \text { Oculomotor apraxia; } \\
\circ \text { Chorea and myoclonus, but tend to resolve with } \\
\text { time; } \\
\circ \text { Neuropathy; } \\
\circ \quad \text { Limb weakness. } \\
\text { - AOA Type } 2 \\
\circ \text { Presents around age } 15 \text { years; } \\
\circ \text { Cerebellar ataxia; } \\
\circ \text { Oculomotor apraxia; } \\
\circ \text { Chorea and myoclonus, persistent; } \\
\circ \text { Neuropathy. }\end{array}$ \\
\hline $\begin{array}{l}\text { Niemann-Pick C } \\
\text { Disease }\end{array}$ & $\begin{array}{l}\text { - Present in childhood; } \\
\text { - } \text { Cerebellar ataxia; } \\
\text { - Vertical supranuclear gaze palsy; } \\
\text { - } \text { Dystonia; } \\
\text { - Liver disease; } \\
\text { - Interstitial lung disease; } \\
\text { - Progressive speech and swallowing difficulties. }\end{array}$ \\
\hline $\begin{array}{l}\text { Spinocerebellar } \\
\text { Ataxias }\end{array}$ & $\begin{array}{l}\text { - Increasing number of genes have been identified. } \\
\text { - Present almost always in adults, rarely in childhood. }\end{array}$ \\
\hline
\end{tabular}

\section{ASSESSMENT OF ATAXIA}

\section{History}

It is important to take a clear and concise history including the timing of onset of symptoms and their progression over time. You need to ask about family history and a developmental history and determine if there has been any developmental regression. Table 5 highlights important points to ask in history. 
Table 5: History taking for ataxia

\section{Associated symptoms}

- Gait disturbance

- Other cerebellar symptoms

- Loss of sensation

- Weakness in upper or lower limbs

- Seizures

- Headache

- Developmental regression

- Skin changes (neuropathy)

\section{Significant aspects}

- Acute, episodic, or chronic onset

- Rate of progression

- Ingestion of substance or alcohol

- Recent illnesses

- Recent trauma or whiplash

- Recurrent infections

- Weight loss

- Developmental regression

- Family history of ataxia (eg, spinocerebellar ataxia, spinocerebellar ataxia)

\section{Examination}

Box 1 summarises the general examination that should be covered. Box 3 and Box 4 summarise the

key features of a cerebellar and sensory examination.

Box 1: General Examination in a child with ataxia

- General observation

- Height, weight, body mass index, head circumference.

- Vital signs including blood pressure, heart rate, respiration rate, temperature.

- Demeanour and behaviour. Mental state.

- Conscious level.

- Posture.

- Dysmorphic features.

- Rashes and skin lesions.

- Gait and posture

- Observe for truncal, limb, and gait ataxia.

- Cranial nerve exam including fundi.

- Muscle bulk, fasciculation, tone, power, joint position sense (see below).

- Cerebellar signs (see Box 2).

- Ear, nose and throat examination.

- Musculoskeletal examination.

- Respiratory \& Cardiovascular examinations.

- Gastrointestinal examination.

Box 2: Cerebellar Signs

\section{Saccades}

Jerky eye movements called hypometric saccades.

Pursuits 
Jerky pursuits or nystagmus near the extremes of gaze. A couple of small beats of nystagmus at the extremes of lateral gaze are normal.

\section{Speech}

Slurring and poor articulation, and especially staccato speech.

\section{Dysdiadochokinesia}

Alternating forearm pronation / supination, if particularly slow or uncontrolled.

\section{Finger-nose test}

Increase in tremor as the finger approaches target: dysmetria.

\section{Tandem gait}

Walking forward and backwards heal to toe with excessive wobble.

Gait

Typically a wide-based and lurching unsteady gait.

\section{Box 3: Sensory Examination}

\section{Joint position sense (JPS)}

This is normally performed on the middle finger and the large toe.

\section{Romberg's test}

If the patient falls, staggers, or becomes much more unsteady, or needs to be supported by the examiner, it is positive that is abnormal. This is a sign of sensory impairment, eg of joint position sense, indicating a neuropathy and or dorsal column spinal cord pathology.

\section{INVESTIGATIONS}

We do not recommend an extensive set of investigations on all children who present with ataxia. A comprehensive history and examination will indicate which investigations are required, in accordance with the differential diagnosis. However, all children presenting with acute ataxia should have toxicology screening (blood and urine) and a blood glucose, and consider requesting a breath or blood alcohol test.

We recommend that all children with new onset ataxia have brain neuroimaging. The mode of neuroimaging will depend on the urgency of the imaging and the imaging modality available (see 
Box 4). MRI is most sensitive and gives most information, however CT is useful in an emergency as it

is quick and can identify some pathologies requiring urgent surgical intervention.

Box 4: Indications for urgent neuroimaging

- Signs of a raised intracranial pressure.

- Focal or asymmetrical neurological signs.

- History of head trauma with new onset ataxia.

- Cranial neuropathies.

- Transient loss of consciousness greater than 5 minutes followed by new onset ataxia.

- Signs of acute encephalopathy.

See tables 6-8 for an approach to the investigation of ataxia.

Table 6: Investigations for ataxia with no obvious cause

\begin{tabular}{|c|c|}
\hline \multicolumn{2}{|c|}{ What investigations should I consider in a child with ataxia and no obvious cause? } \\
\hline $\begin{array}{l}\text { Boxicology } \\
\text { Full blood count and blood film } \\
\text { Lactate and Ammonia } \\
\text { Very Long Chain Fatty Acids } \\
\text { Transferrin isoform electrophoresis for Congenital } \\
\text { Disorders of Glycosylation } \\
\text { Alpha-Fetoprotein } \\
\text { Amino acids } \\
\text { Vitamin E, Cholesterol, } \\
\text { White Cell Enzymes } \\
\text { Ataxia gene panel } \\
\text { Save EDTA sample for future DNA analysis }\end{array}$ & $\begin{array}{l}\text { Urine } \\
\text { Toxicology } \\
\text { Organic acids, orotic acid } \\
\text { Sialic acid } \\
\text { Catecholamines (including vanillylmandelic acid) }\end{array}$ \\
\hline $\begin{array}{l}\text { Imaging } \\
\text { MRI brain and spine } \\
\text { CT Brain (in emergency department setting) }\end{array}$ & $\begin{array}{c}\text { Other tests in selected cases } \\
\text { Nerve conduction studies or electromyography }\end{array}$ \\
\hline
\end{tabular}


Table 7: Investigations for Episodic Ataxia

\begin{tabular}{|c|c|c|}
\hline & Investigations & Results \\
\hline $\begin{array}{l}\text { Genetic Episodic } \\
\quad \text { Ataxias }\end{array}$ & Molecular genetic testing & $\begin{array}{l}\text { Mutations in KCNA1 (Episodic ataxia type 1) or } \\
\text { CACNA1A (Episodic ataxia type2) }\end{array}$ \\
\hline \multirow{4}{*}{$\begin{array}{l}\text { Glucose transporter } \\
\text { Type } 1 \text { deficiency }\end{array}$} & Fasting lumbar puncture & Low CSF glucose, low to normal CSF lactate \\
\hline & Molecular genetic testing & SLC2A1 gene mutation \\
\hline & Brain MRI & Normal, sometimes mild atrophy \\
\hline & EEG & No characteristic pattern \\
\hline \multirow{6}{*}{$\begin{array}{l}\text { Urea cycle enzyme } \\
\text { deficiencies }\end{array}$} & Plasma ammonia & Plasma ammonia >150 micromol/L \\
\hline & Arterial $\mathrm{pH}$, serum lactate, electrolytes & Normal anion gap, elevated lactate \\
\hline & Serum glucose & Normal serum glucose \\
\hline & Plasma amino acids & Abnormal amino acids, depending on condition \\
\hline & Urine organic acids, orotic acid & Can be abnormal \\
\hline & Molecular genetic testing & Recognised mutation \\
\hline \multirow{4}{*}{ Aminoacidurias } & Plasma ammonia & Can have hyperammonaemia \\
\hline & $\mathrm{pH}$, bicarbonate, serum lactate, electrolytes & Metabolic acidosis \\
\hline & Serum glucose & Can have hypoglycaemia \\
\hline & Liver function tests & Liver dysfunction \\
\hline Basilar Migraine & Brain MRI & Normal MRI \\
\hline
\end{tabular}

CSF, cerebrospinal fluid. 
Table 8: Investigations for Progressive Ataxia

\begin{tabular}{|c|c|c|}
\hline & Investigations & Results \\
\hline \multirow{2}{*}{ Cerebellar tumour } & MRI brain & Lesion visualised on MRI \\
\hline & Fundoscopy & Papilloedema \\
\hline \multirow{4}{*}{$\begin{array}{c}\text { Ataxia- } \\
\text { Telangiectasia }\end{array}$} & Genetic testing & Ataxia-Telangiectasia mutated gene mutation \\
\hline & MRI brain & Normal early on with later cerebellar atrophy \\
\hline & Serum Immunoglobulins & Low IgA \\
\hline & Serum Alpha-Fetoprotein & Raised in $90 \%$ of cases \\
\hline \multirow{3}{*}{ Friedreich Ataxia } & Nerve conduction studies & Absent sensory nerve action potentials \\
\hline & Genetic testing & FXN gene mutation due to GAA repeat \\
\hline & MRI brain and spine & Atrophy of cervical spinal cord \\
\hline \multirow[t]{2}{*}{ Multiple Sclerosis } & MRI brain and spine & $\begin{array}{l}\text { Periventricular lesions and discrete white } \\
\text { matter abnormalities. Plaques can be visible in } \\
\text { the optic nerve, brainstem, and spinal cord. }\end{array}$ \\
\hline & Visual evoked potential studies & Slowed responses \\
\hline \multirow{2}{*}{ Vitamin Deficiencies } & Vitamin E levels & Low \\
\hline & Vitamin B12 levels & Low \\
\hline \multirow{5}{*}{$\begin{array}{c}\text { Neurological coeliac } \\
\text { disease }\end{array}$} & Anti-endomysial IgA antibody & Raised \\
\hline & Antitissue transglutamase IgA antibodies & Raised \\
\hline & $\lg A$ & Low \\
\hline & HLA DQ2/8 testing & Positive \\
\hline & Small bowel biopsy & Villous atrophy with crypt hyperplasia \\
\hline
\end{tabular}




\section{SUMMARY}

There are many causes of ataxia in childhood, but they can be grouped into 4 main groups: acute, episodic, chronic non-progressive, and chronic progressive. The type can be subdivided within these groups into pure cerebellar and the other ataxias based on clinical examination. This will help focus the differential diagnosis, and investigation for causes. Through a full clinical history and examination, the investigations required can be determined based on the differential diagnosis. The diagrams (figure 1 ) and tables within this review are a guide to the most common presentations.

Children can present with a variety of symptoms and it remains important to have a wide differential diagnosis. All children should have neuroimaging at some point during their illness.

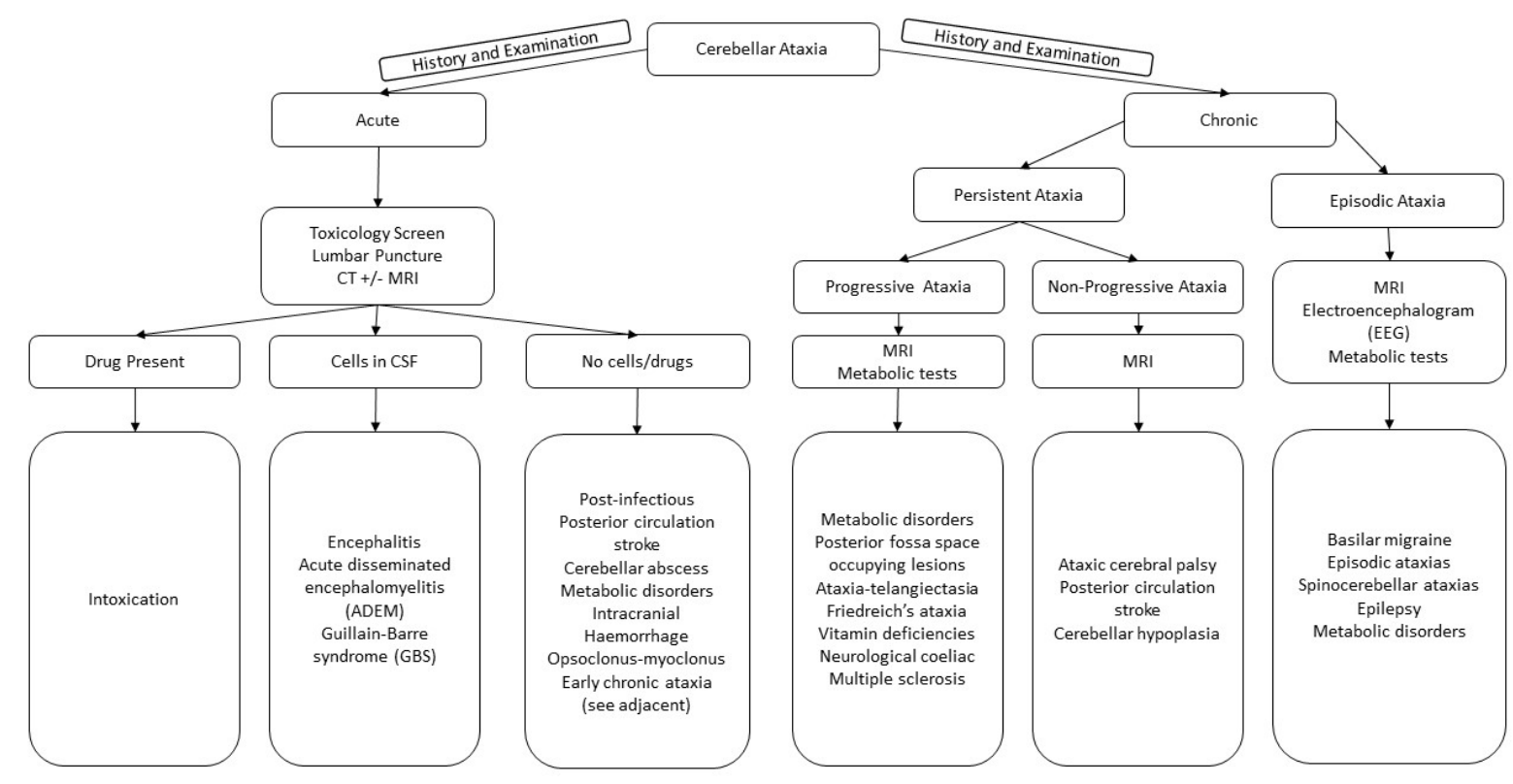

Figure 1 Ataxia in children: early recognition and clinical evaluation. CSF, cerebrospinal fluid.

Adapted from Pavone et al. ${ }^{(28)}$ 
Twitter Shalini Ojha @shaliniojha7

Contributors EP wrote the main manuscript. WPW, MP and SO reviewed and amended the manuscript. The final manuscript was approved by EP, MP, SO and WPW.

Funding: The authors have not declared a specific grant for this research from any funding agency in the public, commercial or not-for profits sectors.

Competing interests: None declared.

Patient consent for publication: Not required.

Data availability statement: There is no data in this work.

ORCID iDs

Emily Petley http://orcid.org/0000-0003-2388-3793

Shalini Ojha http://orcid.org/0000-0001-5668-4227 


\section{REFERENCES}

1. Thakkar K, Maricich SM, Alper G. Acute Ataxia in Childhood: 11-Year Experience at a Major Pediatric Neurology Referral Center. J Child Neurol. 2016;31(9):1156-60.

2. Gieron-Korthals MA, Westberry KR, Emmanuel PJ. Acute Childhood Ataxia: 10-Year Experience. Journal of Child Neurology. 1994;9(4):381-4.

3. Prasad M, Ong MT, Setty G, Whitehouse WP. Fifteen-minute consultation: The child with acute ataxia. Arch Dis Child Educ Pract Ed. 2013;98(6):217-23.

4. Caffarelli M, Kimia AA, Torres AR. Acute Ataxia in Children: A Review of the Differential Diagnosis and Evaluation in the Emergency Department. Pediatr Neurol. 2016;65:14-30.

5. Sivaswamy L. Approach to acute ataxia in childhood: diagnosis and evaluation. Pediatr Ann. 2014;43(4):153-9.

6. Javadzadeh M, Hassanvand Amouzadeh M, Sadat Esmail Nejad S, Abasi E, Alipour A, Mollamohammadi M. Ataxia in Childhood: Epidemiological, Clinical and Neuroradiologic Features, and the Risk of Recurrence. Iranian journal of child neurology. 2017;11(3):1-6.

7. Ryan MM, Engle EC. Acute ataxia in childhood. J Child Neurol. 2003;18(5):309-16.

8. RCPCH. The management of children and young people with an acute decrease in concious level. 2015, revised 2019.

9. Kneen R, Michael BD, Menson E, Mehta B, Easton A, al HCe. Management of suspected viral encephalitis in children - Association of British Neurologists and British Paediatric Allergy, Immunology and Infection Group National Guidelines. J Infection. 2012;64:449-77.

10. Chen Y, Ma F, Xu Y, Chu X, Zhang J. Vaccines and the risk of acute disseminated encephalomyelitis. Vaccine. 2018;36(26):3733-9.

11. Alper G. Acute disseminated encephalomyelitis. J Child Neurol. 2012;27(11):1408-25.

12. Steiner I, Kennedy PG. Acute disseminated encephalomyelitis: current knowledge and open questions. J Neurovirol. 2015;21(5):473-9.

13. Batuecas-Caletrio A, Martin-Sanchez V, Cordero-Civantos C, Guardado-Sanchez L, Marcos $\mathrm{MR}$, Fabian $\mathrm{AH}$, et al. Is benign paroxysmal vertigo of childhood a migraine precursor? Eur J Paediatr Neurol. 2013;17(4):397-400.

14. Brunklaus A, Pohl K, Zuberi SM, de Sousa C. Investigating neuroblastoma in childhood opsoclonus-myoclonus syndrome. Arch Dis Child. 2012;97(5):461-3.

15. Jacob S. Guillain-Barre syndrome. BMJ Best Practice. 2017.

16. Agrawal S, Peake D, Whitehouse WP. Management of children with Guillain-Barré syndrome. Archives of Disease in Childhood - Education and Practice. 2007;92:161-8.

17. Pascual JM, Ronen GM. Glucose Transporter Type I Deficiency (G1D) at 25 (1990-2015):

Presumptions, Facts, and the Lives of Persons With This Rare Disease. Pediatr Neurol. 2015;53(5):379-93.

18. Bireley WR, Van Hove JL, Gallagher RC, Fenton LZ. Urea cycle disorders: brain MRI and neurological outcome. Pediatr Radiol. 2012;42(4):455-62.

19. Grunert SC, Wendel U, Lindner M, Leichsenring M, Schwab KO, Vockley J, et al. Clinical and neurocognitive outcome in symptomatic isovaleric acidemia. Orphanet Journal of Rare Diseases. 2012;7:9.

20. Fernandez-Alvarez E, Perez-Duenas B. Paroxysmal movement disorders and episodic ataxias. Handb Clin Neurol. 2013;112:847-52.

21. Ying G, Fan W, Li N, Wang J, Li W, Tan G, et al. Clinical characteristics of basilar-type migraine in the neurological clinic of a university hospital. Pain medicine (Malden, Mass). 2014;15(7):1230-5.

22. Ramanan $M$, Chaseling R. Paediatric brain tumours treated at a single, tertiary paediatric neurosurgical referral centre from 1999 to 2010 in Australia. J Clin Neurosci. 2012;19(10):1387-91.

23. Parkinson MH, Boesch S, Nachbauer W, Mariotti C, Giunti P. Clinical features of Friedreich's ataxia: classical and atypical phenotypes. J Neurochem. 2013;126 Suppl 1:103-17. 
24. Bigi S, Banwell B. Pediatric multiple sclerosis. J Child Neurol. 2012;27(11):1378-83.

25. Manjunatha YC, Gupta AK, Gupta SK. Subacute combined degeneration of the spinal cord in a child. Indian J Pediatr. 2011;78(2):240-1.

26. Rahmoune H, Boutrid N, Amrane M, Chekkour MC, Bioud B. Ataxia in children: think about vitamin E deficiency ! (comment on: ataxia in children: early recognition and clinical evaluation). Ital J Pediatr. 2017;43(1):62.

27. Suthar R, Sankhyan N, Thapa BR, Singhi P. Proximal Myopathy: A Rare Presentation of Celiac Disease. J Child Neurol. 2013;28(11):1485-8.

28. Pavone $P$, Pratico AD, Pavone $V$ et al. Ataxia in children:early recognition and clinical evaluation. Ital J Pediatr 2017;43:6. 